ROCZNIKI FILOZOFICZNE

Volume LXIX, issue 3-2021

DOI: https://doi.org/10.18290/rf21693-1

ELEONORE STUMP

\title{
THEOLOGY AND THE KNOWLEDGE OF PERSONS*
}

\section{INTRODUCTION}

What is the right methodology for studying theology? This question is of course dependent on another: What is theology? The right methodology for any discipline depends on what the discipline is studying. If you are studying molecules, the methods of economics or psychology are unlikely to be helpful. So what is theology, what is its subject, and what methodology is useful for understanding its subject?

In contemporary times, theology has often been regarded as philosophy with a special set of authorities to which it defers. On this characterization of theology, it differs from philosophy mainly by being insufficiently open to reason. On this view, philosophy takes its premises from reason alone, whereas theology is willing to take some of its premises from religious authority, from revealed texts, from creeds, or from some other magisterial source. On this view, because philosophy takes its premises from reason alone, it is shareable by everybody. And because theology takes its premises from authority of some sort, it will be acceptable only to people who share some particularity, of religious identification or church membership or something else of the sort. On this characterization of theology, then, philosophy is universal and impartial; theology is particular and partisan.

Eleonore Stump, Robert J. Henle Professor of Philosophy, Sains Louis University; correspondence address: 3826 Castleman Avenue, Saint Louis, MO 63110, USA; e-mail: eleonore.stump@slu.edu; ORCID: https://orcid.org/0000-0002-6983-5562.

${ }^{*}$ The paper was originally published in: Fiona Ellis (ed.), New Models of Religious Understanding (Oxford: OUP, 2017), 172-90. Reprinted by the permission of the Author. 
This is an Enlightenment sort of view of both theology and philosophy, of course. The Enlightenment thought that all reputable learning is a universal or generically human enterprise based on reason alone. This belief is part of the view now generally called "modernism." In philosophy as in science, modernists have thought, we should put aside all our particularities - of gender, race, nationality, religion, and social class - and enter impartially into the project of learning just as the generic human beings we are.

But it is hard to know who would now whole-heartedly endorse this way of identifying philosophy and theology. On the contrary, we have learned to be skeptical of the whole Enlightenment view that seemed to support it.

Postmodernism, of course, rejects the entire modernist picture. On the view of postmodernists, there is no such thing as universal, impartial reason. All reason is particularist and perspectival, and philosophy can differ from theology only in hiding from itself that it is as particularist as theology is. On this postmodernity perspective, philosophy and theology both begin with authoritative teaching of a particularist kind. They just pick different particularities as their starting points.

The ongoing debate over postmodernism has brought to the fore the relativism lurking not far below the surface of most ordinary forms of postmodernism, a relativism that even many postmodernists would like to deny. But whatever the right resolution of the debate over postmodernism may be, what postmodernism has made everyone self-conscious about is the way in which claims to rely only on universal and impartial reason are unrealistic. All human learning and reasoning have to begin somewhere, with some set of assumptions; and those assumptions are typically drawn from authority of one sort or another. In fact, philosophers are now increasingly interested in the fact that much of what we think we know comes from the testimony of others. Human cognition, like many other human activities, is a social matter and relies on the activity of a community; it is not the work of any one individual in isolation. The transfer of information and perspectives through authority and testimony is crucial to human knowledge. So it is not any longer promising to see the difference between theology and philosophy as a matter of philosophy's employing reason alone and theology's being bound to authority.

In my own view, the names of the disciplines give us a more promising way to think about each of them and so also a more profitable way to think about the nature of theology. The name "philosophy" in its etymology means 
something like the love of wisdom. The name "theology" in its etymology means something like the word with regard to God. ${ }^{1}$

Now wisdom is well suited to be thought of as an abstract universal. In this respect, it is like redness or love. It is not a substance; it does not have any particular dimensions; and it cannot exert causal power or receive the effects of anything else's causal action. In this respect, wisdom is different from a wise person, say, or a loving person or a red thing. A red thing will have a certain dimension, and it will have certain causal powers that it can exercise, and so on. A red thing, a loving person, and a wise person are concrete particulars. Wisdom, which philosophy seeks, is not.

On the other hand, it is clear that the God with regard to whom theology seeks the word cannot be construed as an abstract universal. On the view of all the Abrahamic monotheisms, God is characterized by mind and will. But nothing that is an abstract universal could have mind and will. In fact, the God of the major monotheisms is omniscient and omnipotent; but no abstract universal can know anything at all or do anything at all. So whatever the God of theology is, God is not like wisdom in being an abstract universal. Rather, in virtue of being characterized by mind and will, God is more nearly a person (in our sense of the word "person") than an abstract universal. (I am not forgetting the doctrine of divine simplicity here. But even so committed an adherent to the doctrine as Aquinas nonetheless supposes that a simple God is characterized by mind and will. ${ }^{2}$ ) The wisdom philosophy seeks is impersonal. A philosopher can seek wisdom, but wisdom cannot seek him. A philosopher can love wisdom, but wisdom cannot love him back. The God of the major monotheisms, however, can seek a theologian and love her before she seeks or loves him.

In my view, the nature of theology is illuminated most centrally in this difference between philosophy and theology. It makes a great difference to one's method of seeking and one's view of the nature of depth in understanding whether what one is seeking is an abstract universal such as wisdom or a person with a mind and a will.

\footnotetext{
${ }^{1}$ I have picked this clumsy rendering of the etymological sense of "theology" in an attempt to preserve the amphiboly of the expression. The word in question can be either the output of reason with respect to God or the Logos, who is the second person of the Trinity.

${ }^{2}$ I have discussed in detail the connection between the doctrine of simplicity and this understanding of the nature of theology in my "Athens and Jerusalem: The Relationship of Philosophy and Theology" (Journal of Analytic Theology). This introduction is largely taken from that paper.
} 


\section{GOD AS A PERSON: THE DOCTRINE OF SIMPLICITY}

Some people will resist this characterization of theology because of their adherence to the doctrine of simplicity. Simplicity is standardly accepted as one of the divine attributes by virtually all Christian thinkers in the Patristic and medieval periods, as well as by major philosophers and theologians in the Jewish and Islamic traditions. It is one of the most difficult divine attributes to understand but also one of the most important.

The doctrine of simplicity is sometimes interpreted as implying that God is being itself, or esse alone (to put the point in Latin). On this interpretation of the doctrine, contrary to what I have been claiming in characterizing theology, it is false to say of God that God is a concrete particular, a being - an id quod est (a "that which is"). And if God is not a concrete particular or a being at all, then a fortiori God is not a person with a mind and a will.

But, in my view, this is an interpretation of the doctrine of divine simplicity that is seriously misleading at best and false at worst. ${ }^{3}$

Aquinas is one of the primary promoters of the doctrine of divine simplicity, and we can see a more suitable interpretation of the doctrine by looking at his exposition of it. On Aquinas's view, we cannot know the quid est of God. That is, we cannot know what kind of thing God is, even when it comes to the distinction between an abstract universal and a concrete particular. So, for example, Aquinas says: "With regard to what God himself is (secundum rem), God himself is neither universal nor particular."

On Aquinas's view, God's nature is such that there is something false about conceiving of it either as esse alone or as id quod est alone. For this reason, Aquinas thinks, we have to exercise care in the way we frame our claims about God. It is acceptable to say that God is esse, being itself, provided we understand that this claim does not rule out the claim that God is id quod est, an entity, a concrete particular. Aquinas puts the point this way:

Those material creatures that are whole and subsistent are composite. But the form in them is not some complete subsisting thing. Rather, the form is that by means of which some thing is. For this reason, all the names imposed by us to signify some complete

\footnotetext{
${ }^{3}$ I have argued for this claim in detail elsewhere. See my The God of the Bible and the God of Philosophers, "Aquinas Lecture." See also my "God's Simplicity," in The Oxford Handbook of Aquinas, ed. Brian Davies and Eleonore Stump (Oxford: OUP, 2011), 135-46; and "Simplicity and Aquinas's Quantum Metaphysics," in Die Metaphysik des Aristoteles im Mittelalter: Rezeption und Transformation, ed. Gerhard Krieger (Berlin: De Gryuter, 2016), 191-210.

${ }^{4} S T h$, I q. 13 a. 9 ad 2. The translations of Aquinas's texts in this paper are mine.
} 
subsisting thing signify in the concrete, as is appropriate for composite things. But those names that are imposed to signify simple forms signify something not as subsisting but rather as that by means of which something is, as for example "whiteness" signifies that by means of which something is white. Therefore, because God is both simple and subsistent, we attribute to God both abstract names - to signify God's simplicity — and concrete names - to signify God's completeness and concreteness. Nonetheless, each kind of name falls short of God's mode [of being], just as our intellect does not know God as he is, in this life. ${ }^{5}$

And so, on Aquinas's view, it is correct to say that God has a mind and a will, even though nothing could have a mind and a will unless it were a concrete particular. The doctrine of simplicity does not require rejecting as false the claim that God is a being, a concrete particular. It requires only a recognition that it is also correct to say that God is esse itself. As I have argued elsewhere, the doctrine of simplicity mandates a kind of quantum theology, an analogy to quantum physics. ${ }^{6}$ It is correct to say that light is a wave; it is correct to say that light is a particle; and nothing about these claims implies that one and the same thing at the same time is both a wave and a particle. Since the analogous claims hold as regards God, on Aquinas's view, then the doctrine of simplicity does not rule out the claim that God is a being with a mind and a will. Consequently, even on the doctrine of simplicity, it is correct to say that God is a person, in our sense of the word "person."

\section{THE KNOWLEDGE OF PERSONS}

In this connection, it is important to see that propositional knowledge is not the only kind of knowledge possible for human beings. As I have argued in detail elsewhere, ${ }^{7}$ there is a different kind of knowledge available to human beings which is not reducible to knowledge that something or other is the case, and it does not depend on the grasp of the quiddity of a thing. This is the knowledge of persons. ${ }^{8}$

To get some intuitive feel for this non-propositional knowledge of persons, imagine a woman Mary who has been kept in isolated imprisonment since

\footnotetext{
${ }^{5}$ STh, I q. 13 a. 1 ad 2. Cf. also $S C G$, I c. 30.

${ }^{6}$ See, for example, my "God's Simplicity," 135-46.

${ }^{7}$ See my Wandering in Darkness. Narrative and the Problem of Suffering (Oxford: OUP, 2010), chap. 1-4.

${ }^{8}$ Or, more accurately, it includes the knowledge of persons. For a discussion of the other varieties of this non-propositional knowledge, see my Wandering in Darkness, chap. 4.
} 
birth by some mad scientist. Imagine that Mary, in her imprisonment, has had access to any and all information about the world which can be transmitted in terms of propositions. ${ }^{9}$ So, for example, Mary has available to her the best science texts for any of the sciences, from physics to sociology. She knows that there are other people in the world, and she knows all that science can teach her about them. But she has never had any personal interactions of a direct and unmediated sort with another person. She has read descriptions of human faces, for example, but she has never been face-to-face with another person. ${ }^{10}$ And then suppose that Mary is finally rescued from her imprisonment and united for the first time with her mother, who loves her deeply.

When Mary is first united with her mother, it seems indisputable that Mary will know things she did not know before, even if she knew everything about her mother which could be made available to her in expository prose. Although Mary knew that her mother loved her before she met her, when she is united with her mother, Mary will learn what it is like to be loved. And this will be new for her, even if in her isolated state she had as complete a scientific description as possible of what a human being feels like when she senses that she is loved by someone else. What will come as the major revelation to Mary is her mother. Even this way of putting what Mary learns is misleading, because it suggests that Mary's new knowledge can be expressed in a thirdperson description of her mother. But neither first-person nor third-person accounts will be adequate for Mary to describe what is new for her. What is new for her, what she learns, has to do with her personal interaction with another person. What is new for Mary is a second-person experience.

This thought experiment thus shows that we can come to know a person and that this knowledge is difficult or impossible to formulate in terms of propositional knowledge.

The rapid, perplexing increase in the incidence of autism has led scientists and philosophers to a deeper understanding of the knowledge of persons and a new appreciation for its importance in typical human functioning. Various

\footnotetext{
${ }^{9}$ I am here adapting Frank Jackson's original thought experiment. For this and the extensive discussion it has generated, see: Peter LudLow, Yujin NAGASAWA, and Daniel STOLJAR (eds.), There's Something about Mary: Essays on Phenomenal Consciousness and Frank Jackson's Knowledge Argument (Cambridge, MA: MIT Press, 2004).

${ }^{10}$ More than one person has suggested to me that if Mary had been kept from all second-person experiences, she could not have learned a language, and she would be unable to read. But this objection seems to me insufficiently imaginative. We can suppose that Mary has been raised in a sophisticated environment in which carefully programmed computers taught her to speak and to read.
} 
studies have demonstrated that the knowledge which is impaired for an autistic child cannot be taken as knowledge that something or other is the case. An autistic child can know that a particular macroscopic object is her mother or that the person who is her mother has a certain mental state. But the autistic child can know such things without the knowledge that a typically developing child would have. For example, an autistic child might know that her mother is sad, but in virtue of the impairment of autism she will not be able to know the sadness of her mother. And these are different items of knowledge. An autistic child might know that the person she is looking at is sad because, for example, someone who is a reliable authority for the child has told her so. But this is clearly not the same as the child's knowing the sadness in the face of the person she is looking at. ${ }^{11}$

In these cases, and in many other cases of perfectly ordinary human experience, it is arguable that it is not possible to express adequately what is known in terms of propositional knowing. Rather, it is a knowledge of persons.

Mutatis mutandis, the same distinction applies where God is concerned. Consider, for example, these two claims:

(1) Thomas Aquinas knew that God is really present in the Eucharist. and

(1') Thomas Aquinas knew the real presence of God in the Eucharist.

These are clearly not equivalent claims, and the second cannot be reduced to the first. Obviously, the first could be true and the second could be false. Or consider this pair of claims:

(2) Thomas Aquinas knew that God exists. and

(2') Thomas Aquinas knew God.

Here, too, the claims are not equivalent, and the second cannot be reduced to the first. In both these cases, what is at issue in the first sentence is propositional knowledge, and what is at issue in the second is the knowledge of persons with regard to God.

Because what theology seeks to know and understand as its object is something with a mind and a will - a person, in our sense of the word "person"then theology has to be sensitive to the fact that the knowledge of persons is

${ }^{11}$ See Derek Moore, Peter Hobson, and Anthony LeE, “Components of Person Perception: An Investigation with Autistic, Non-Autistic Retarded and Typically Developing Children and Adolescents," British Journal of Developmental Psychology 15, no. 4 (1997): 401-23. 
not reducible to propositional knowledge. The methodology of theology cannot be the same as the methodology of philosophy, or the methodology of the empirical sciences either. It is obviously possible to get to know a person by studying his biology, chemistry, and physics; but one will not know him by this means. Even a study of his psychology is no substitute for knowing him, as the thought experiment about Mary makes clear.

Insofar as the subject-matter of theology is a person, then, the methodology it employs must be different from the methodology used by the sciences or even the methodology customary in philosophy. The sciences and philosophy can contribute useful and important information about a person. The sciences can give information about whether a person has cancer, for example; philosophy can yield understanding about whether a person has free will. But to know a person requires more than information of this sort, and the ordinary methodologies of the sciences and philosophy are insufficient to provide what is lacking.

In addition, and equally importantly, knowledge of persons is susceptible to its own particular kinds of fragmentation. So, for example, just as it is possible to know that $p$ without knowing that one knows that $p$, so it is also possible to know a person without awareness of having knowledge of that person, under some other description of that person. So, for example, a person Paula could know the pauper Jerome and still believe sincerely of herself that she does not know the prince, even if Jerome is the prince, only in disguise as a pauper. And this is only the beginning of the list of the particular characteristics of the knowledge of persons. That this kind of knowledge has its own features, not identical to the features of propositional knowledge, makes a difference to the methods of theology too.

\section{KNOWLEDGE OF PERSONS AND DIVINE HIDDENNESS}

To illustrate the way in which reflection on the knowledge of persons makes a difference to theological discussion, consider, for example, the problem of divine hiddenness. Beginning with a forceful statement of the problem by John Schellenberg, ${ }^{12}$ this has been the subject of much discussion in the recent literature. Schellenberg argued that the fact of divine hiddenness could support

12 J. L. SChellenberg, Divine Hiddenness and Human Reason (Ithaca, NY: Cornell University Press, 1993). His most recent views on the topic of divine hiddenness can be found in his The Hiddenness Argument: Philosophy's New Challenge to Belief in God (Oxford: OUP, 2015). 
an argument for the non-existence of God. Basically, stripped of many careful nuances, his argument goes like this.

Suppose that there is an omniscient, omnipotent, perfectly good God. Then:

(1) An omniscient, omnipotent, perfectly good God is able to give every person knowledge of God's existence and wants to do so

(2) If there are people who do not know that God exists, then either (a) those people are resistant to the knowledge of God's existence, or (b) God is unable or unwilling to give them that knowledge.

(3) There are some people who do not know that God exists.

(4) Therefore, either those people are resistant to that knowledge or God is unable or unwilling to give them that knowledge.

(5) There are some people who do not know that God exists but who are not resistant to that knowledge.

(6) Therefore, God is unable or unwilling to give some people this knowledge-reductio (since 4 contradicts 1 ).

(7) Therefore, it is not the case that there is an omniscient, omnipotent, perfectly good God.

Schellenberg assumes what many people would find uncontroversial, namely that the God of the major monotheisms wants a loving relationship with human beings but that a person's loving relationship with God requires that that person have knowledge of God's existence. Then the heart of Schellenberg's argument is this dilemma: when a person lacks knowledge of God's existence, either that person is responsible for this lack of knowledge or God is. But God can't be responsible for this lack of knowledge, since he is able to give the knowledge and he wants loving relationships, which require knowledge of God's existence. So the only alternative is to suppose that an atheist is himself responsible for his lack of knowledge of God's existence. But this alternative is unpalatable to most people, because it seems to assign culpability for disbelief or blameworthy resistance to belief to every atheist; and so this alternative seems not only false but reprehensible. Consequently, we have Schellenberg's conclusion: the hiddenness of God argues for the non-existence of God.

Schellenberg's argument is typically cast in terms of knowledge that. The question concerning Schellenberg is how to understand the fact that there are people who do not know that God exists. But what is essential to a loving relationship with another person is not knowledge that but knowledge of 
a person. And knowledge of a person can be had without propositional knowledge that that person exists.

Return to the example of Mary isolated by a mad scientist and revise the example a little. Suppose that when Mary first meets her mother, the mad scientist contrives somehow to send her evidence that she is hallucinating. And suppose that, on the basis of this evidence, Mary believes that her perception of her mother is a hallucination. Then, in fact, Mary will have knowledge of her mother without believing that her mother exists, and so she is also without knowledge that her mother exists. In this case, Mary has full and robust knowledge of her mother without knowledge that her mother exists.

It is also possible to have a more attenuated knowledge of another person without knowledge that that person exists. So, for example, in Tolkien's Lord of the Rings, Frodo is rescued from Black Riders by an Elf Lord who carries him off on his horse while Frodo is delirious with fever. Frodo is conscious enough to know the Elf; but in his delirious state he supposes that he is dreaming his rescue. He has some knowledge of the Elf, even in his delirious condition, but he nonetheless does not know that the Elf exists because he supposes that he is dreaming.

Finally, it is also possible to know a person and know that that person exists but to know that person under only one description and not under other relevant descriptions. So, for example, a child living next door to the mayor of his town, but not knowing that his next-door neighbor is the mayor, may know that his neighbor Frank exists but not know that the mayor exists.

It is noteworthy that in none of the three cases above is there anything culpable about the person who lacks knowledge that someone who is known to him with knowledge of persons exists. And there is nothing in these cases either to suggest that a person who lacks such knowledge that must be resistant to it. There is nothing to blame, no aspersions to cast, in this lack of propositional knowledge. On the contrary, as the examples show, it is even possible for someone to have a loving relationship with a person while lacking knowledge that that person exists. Even in the last case, the child who does not know that the mayor exists nonetheless might have a loving relationship with his neighbor, who, unbeknownst to the child, is the mayor.

In fact, actual cases like this with respect to God can be found. So, for example, consider an incident related by the eminent anthropologist Colin Turnbull in his study of Pygmies. On one occasion, the Pygmy serving as Turnbull's aide and guide crossed paths with a Catholic priest, Father Longo, while the Pygmy was guiding Turnbull. Father Longo, unaware of the prime 
directive of anthropologists not to alter the character of the native people under study, took the opportunity of the meeting with the Pygmy to try to evangelize him. According to Turnbull, the Pygmies have a religion of their own. Without much in the way of theology or established religious institutions, they believe in a god of the forest in which they live and whose children they hold themselves to be. In general, the Pygmies Turnbull knew were entirely insulated from contact with Christian beliefs. Apart from connection to Turnbull and this one contact with a Catholic priest, the Pygmy guiding Turnbull had no contact with Christian culture. Nonetheless, as Turnbull himself tells the story, after the encounter with the priest, the Pygmy guide told Turnbull, "Pere Longo was right; this God must be the same as our God in the forest." ${ }^{.13}$ Whether or not this anecdote is trustworthy, it makes the point. On Turnbull's story, before the Pygmy met the Catholic priest, it would not have been true to say that the Pygmy believed that an omniscient, omnipotent, perfectly good God exists; but it was still true, on the Pygmy's view of it, that the Pygmy knew God.

And here it is also important to remember the other implication of the doctrine of simplicity: that it is true to say that God is being, as well as true to say that God is a being with a mind and a will. Being is correlative with goodness ${ }^{14}$; and therefore, on the doctrine of simplicity, it is also true to say that God is goodness. Furthermore, beauty is goodness under a particular description; as Aquinas puts it, beauty is goodness perceptible to the senses (where intellectual vision counts as a kind of sight, too). So in knowing goodness or in sensing beauty, a person is also knowing God, to one degree or another.

So from a person's sincere self-report that he does not believe in an omniscient, omnipotent, perfectly good God, it does not follow that he does not know God in any way or to any degree. And, clearly, knowing God is not a transparent matter. A person can know God through sensing beauty or through second-personal connection of however limited or dreamy a means, without being aware that he has this knowledge of God. A fortiori, it is not clear how others would determine whether a person had knowledge of God. As far as that goes, it is in theory possible, and compatible with the data that many people report themselves to be atheists, that all persons have some knowledge of God. I am not claiming that it is true that all persons have some knowledge of God; I am claiming only that it takes more than self-reports of atheism to show that it is false.

\footnotetext{
${ }^{13}$ Colin Turnbull, The Forest People (New York: Simon and Schuster, 1968), 258.

${ }^{14}$ For an explanation and defense of this claim, see my Aquinas (New York and London: Routledge, 2003), chap. 2.
} 
Of course, one might suppose (as Schellenberg does) that an omniscient, omnipotent, perfectly good God could unilaterally provide a human person with awareness of God powerful enough to bring a person to conscious awareness of God, so that there would be no self-reports of atheism. But here too it makes a difference if we think in terms of knowledge of persons.

Central to Schellenberg's thought is the claim that God wants loving relationships with human beings. But if the knowledge requisite for such a relationship is knowledge of persons, then it seems clear that God cannot unilaterally bring about such knowledge in a human person. Consider just two human persons, Jerome and Paula, and suppose that Jerome wants loving relations with Paula. Then certainly Jerome can jump out in front of Paula and yell "Hi!" to bring it about that Paula acknowledges his existence. But Paula will hardly get to know Jerome by this means. Furthermore, knowledge of persons comes in degrees. If Jerome wants Paula really to know him, not only will he have to go slowly, but he will also have to proceed with her consent. Without her consent, he may bring it about that Paula knows that Jerome exists, but this knowledge on Paula's part will not give Jerome want he wants. To know Jerome, Paula has to be willing to know Jerome. Unlike propositional knowledge of Jerome's existence, the knowledge of Jerome is not something that Jerome can unilaterally produce in Paula.

Without Paula's willingness to be open to Jerome, she will not get to know him. ${ }^{15}$ By parity of reasoning, the knowledge of God is not something that God can produce unilaterally in a human person. But, contrary to Schellenberg, it does not follow either that if a person Paula does not have knowledge of God, she must be somehow resistant to having such knowledge or, if she is resistant, she must be somehow culpable for being resistant.

It is, of course, possible that she might be culpable for her resistance. She might, for example, hate people and so try to avoid knowledge of them. But then again she might not. There are many reasons why Paula might be resistant to being willing to know Jerome, and not all of them are culpable. She might just be highly introverted by nature, for example. In such a case, she might be closed to another person like Jerome without being blameworthy for her condition.

Furthermore, it might be the case that Paula is closed to Jerome without being particularly resistant to knowledge of him. She might be too overwhelmed by life to be available for personal relations, or she might be traumatized by earlier experience, or she might be broken by sorrow and grief. In conditions

\footnotetext{
${ }^{15}$ For more discussion and defense of this point, see STUMP, Wandering in Darkness, chap. 6.
} 
such as these, Paula will not be available for knowledge of Jerome, but for reasons other than her being resistant to belief that Jerome exists.

As far as that goes, it might even be the case that a person who sincerely believes of herself that she longs for Jerome might nonetheless also be unwilling to be open to Jerome. Paula might be unwilling to know Jerome even while she believes truly that she wants to know him, because Paula is internally divided within herself. When Catullus says of his beloved Lesbia, "Odi et amo" ("I hate her and I love her"), no one has difficulty understanding what he means. The tendency to be internally fragmented, to will against what one also wills or even against what one wants to will, is a common human condition, as Augustine pointed out long ago. ${ }^{16}$ So from the fact that a person believes of himself that he is willing to be available for personal relationships with others, including God, it does not follow that he is not also unwilling. And his unwillingness need not be a result of any culpable defect or an indication of any resistance to a particular belief, such as belief that God exists. The complexity of human psychology allows for many other sources of such internal division in the self.

Consequently, Schellenberg is wrong. There are more alternatives available for explaining the apparent hiddenness of God than the two he gives, namely either that human beings are culpably resistant to belief, or else that human beings haven't been given belief, or the basis for belief, by God, so that there is no omniscient, omnipotent, perfectly good God.

It makes a huge difference to theological discussion, then, if we think of the subject of theology as a God who is somehow both being itself and also a being, something which has a mind and a will. And if we recognize that knowledge of a person is different from propositional knowledge with regard to that person, we will see even some much-discussed theological problems in a new way.

\section{THEOLOGY AND NARRATIVE}

The preceding reflections illuminate the role of the knowledge of persons in particular theological discussion, but focusing on the knowledge of persons also makes a difference to a more general understanding of the methodology useful to theology.

We are not yet in a position to give a clear and complete account of the knowledge of persons; but however exactly we are to describe it, it cannot be

\footnotetext{
${ }^{16}$ For further discussion and defense of this view, see STUMP, Wandering in Darkness, chap. 7.
} 
captured appropriately as knowledge of either a first-person or a third-person kind. As I have argued in detail elsewhere, it is more nearly accurate to describe it in terms of a second-person experience. ${ }^{17}$ In earlier work, I characterized the second-person experience one person Paula has of another person Jerome in this way. ${ }^{18}$ Paula has second-person experience of Jerome only if Paula is aware of Jerome as a person; her awareness is direct, intuitive, and unmediated; and Jerome is conscious. The knowledge enabled by such an experience is the knowledge of persons. Knowledge of persons is therefore a kind of second-personal knowledge.

One of the noteworthy things about the second-person knowledge of persons is that it can be transmitted by means of stories. While a person cannot express the distinctive knowledge of his second-personal experience as a matter of knowing that, he can do something to re-present the experience itself in such a way that he can share the second-person experience to some degree with someone else who was not part of it, so that at least some of the knowledge of persons garnered from the experience is also available to her. ${ }^{19}$ And this is generally what we do when we tell a story. ${ }^{20}$

So a story can be thought of as a report of a set of real or imagined secondperson experiences that does not lose (or at least does not lose entirely) the distinctively second-person character of the experiences. A story does so by making it possible, to one degree or another, ${ }^{21}$ for a person to experience some of what she would have experienced if she had been an onlooker in the secondperson experience represented in the story. That is, a story gives a person some of what she would have had if she had had unmediated personal interaction with the characters in the story while they were conscious and interacting with each other, without actually making her part of the story itself. ${ }^{22}$

\footnotetext{
${ }^{17}$ Ibid., chap. 4.

${ }^{18}$ For more discussion of the second-personal, see ibid., chap. 4 and 6.

${ }^{19}$ In this respect, a second-person experience differs from a first-person experience of the sort we have in perception. There is no way for me to convey to someone who has never seen colors what I know when I know what it is like to see red.

${ }^{20} \mathrm{I}$ am not here implying that the only function, or even the main function, of narratives (in one medium or another) is to convey real or imagined second-person experiences. My claim is just that much less is lost of a second-person experience in a narrative account than in a third-person account, ceteris paribus.

${ }^{21}$ The degree will be a function not only of the narrative excellence of the story but also of the sensitivity and intelligence of the story-hearer or reader as well.

${ }^{22}$ I do not mean to say that the storyteller or artist does not contribute something of her own in the narrative presentation. On the contrary, part of the importance of narrative is that its artistry enables us to see what we might well have missed without the help of the narrative, even if we had
} 
What is noteworthy here, then, is that, to one degree or another, a story about a person Jerome can connect another person Paula with Jerome in such a way that, although Paula is not face-to-face with Jerome, she nonetheless has a kind of second-person experience of Jerome ${ }^{23}$; and because of that experience gained through the story, she has some knowledge of persons with respect to Jerome. (How much knowledge she has will be a function of how well the story is told and of how competent Paula is at the comprehension of stories. ${ }^{24}$ )

When the knowledge of persons has to do with God, then it is worth noticing that most people acquire that knowledge, at least originally, from biblical stories, either by hearing or reading the stories for themselves or by hearing the stories in brief as summarily recounted by others. So, for theology, narrative is central to the pursuit of the knowledge that is theology's object. And this makes a huge difference to the methodology suitable for theology.

In this connection, consider again the difference between theology and philosophy. Philosophical work, especially in the analytic tradition, commonly has a certain sort of tight order to it because it is structured around arguments, and philosophical discussion typically proceeds in an orderly way designed to try to command agreement. By contrast, interpretations of narratives - for that matter, interpretations of people and their actions - do not admit of rigorous argument. We can definitively rule some interpretations out, but it is hard to make a compelling argument that only this interpretation is right. Even a carefully supported interpretation of narratives is, in effect, only a recommendation to look at a text in a certain way. It invites readers to consider that text and ask themselves whether after all they do not see the text in the way the interpretation recommends. Interpretations present, suggest, offer, and invite; unlike philosophical arguments, they cannot attempt to compel.

Furthermore, the interpretation of narratives is itself an art; it requires its own kind of expertise. And for narratives, as for philosophy, there is a community of scholars in whom that expertise is vested. Although communal expertise

been present as bystanders in the events recounted in the narrative. It is for this reason that the quality of the artistry in a narrative makes a difference to what there is to know on the basis of it.

${ }^{23}$ Or an analog to a second-person experience. Whether it is a real second-person experience or an analog to one is a complicated matter that cannot be dealt with adequately in passing here.

${ }^{24}$ For the sake of space, I am here simply presupposing that the story in question is historically true in its details. It is an interesting but complicated question what happens to these claims if the story is fictional in every respect. There are certainly some people who suppose that these claims remain entirely true even in such a case. That is, there are people who suppose one can have a second-person experience and knowledge of persons with regard to, for example, Trollope's endearing Duchess of Omnium. It would take me too far afield here, and it is not necessary for my purposes in any case, to pursue this issue in this chapter. 
can certainly be mistaken, it is not generally wise to jettison it wholesale. It represents the results of many minds working in community over a considerable period of time. This is the case for the study of narratives just as it is for the study of philosophy. In the case of narratives, one thing this communal expertise typically gives us is a plethora of interpretations of a text. It shows us the range of interpretations possible as regards that text, and so it makes us more thoughtful and more sophisticated in our interpretation of that text. It also shows us what needs to be done to support a particular interpretation of a text. It helps us understand what interpretations need to be argued against if one particular interpretation is to be put forward as the most plausible or most fruitful one.

These remarks apply to narrative texts in our own culture and language, but they are especially pertinent when the narratives in question are written in a language very different from our own and stem from a culture very different from our own. In the case of the biblical texts, even before the difficulties of interpreting the text, there is the difficulty of finding the right reading of it. Just understanding what a line means can take considerable expertise. For such texts, the work of generations of linguists, historians, and literary scholars can yield insight into readings and interpretations that would be hard to come by otherwise. In the case of the stories in the Bible, the texts have been studied for centuries by some of the best minds in the Jewish and Christian traditions; and many of the commentaries of those scholars, with their philological and literary competences, are still available to us. And, of course, the biblical texts are still very much under discussion today, not only by historical biblical scholars and literary critics but even by philosophers.

Finally, many ancient and contemporary studies make clear to us that the biblical narratives in particular have neutron-star density. For example, Eric Auerbach has famously contrasted the narratives of the Hebrew Bible with the narratives of Homer, to bring out the biblical narrative's ability to convey an enormous amount with a tiny bit of text. ${ }^{25}$ The noted literary scholar Robert Alter has made contemporary readers aware of what can be done with the Hebrew narratives when their detail is unfolded by someone trained in the analysis of narratives and attentive to the nuances of ancient Hebrew poetry and prose. ${ }^{26}$

So theology needs to consider narratives, and especially biblical narratives, as well as philosophical or theological issues. And then it needs to treat those narratives not just as historical artifacts but rather as the stories they are.

\footnotetext{
${ }^{25}$ Erich AuERBACH, Mimesis: The Representation of Reality in Western Literature (Princeton NJ: Princeton University Press, 2003).

${ }^{26}$ See, for example, Robert Alter, The Art of Biblical Narrative (New York: Basic Books, 1991).
} 
To consider them as stories is to bring to bear on them all the tools scholars of narrative have developed for such study and to avail oneself of the archive of scholarship produced by others engaged in the same enterprise.

\section{CONCLUSION}

Considered as a discipline, then, theology differs from philosophy in having as its subject matter a God who has a mind and a will, even on the doctrine of simplicity, which takes God to be somehow also being itself. Consequently, what theology seeks with respect to God includes the knowledge of persons; it needs more than knowledge that. But the knowledge of persons is a special kind of knowledge that cannot be captured completely or even at all in expository, propositional prose. Even so, this special kind of knowledge is sharable, particularly through the medium of narratives. For theology then, unlike philosophy, narratives are central to its methodology. For this reason, it needs to avail itself of all the skills and expertise of those sensitive to narratives. History and philosophy matter to theology, but the understanding of narrative matters more. Elsewhere I argued that philosophy is impoverished if it does not avail itself of the knowledge of persons mediated by narratives. But I meant that, in some cases, philosophy will be enriched in its propositional knowledge of universals such as wisdom if it makes its way to that knowledge through narrative. But the case for theology is different. Because the end point for philosophy is the knowledge of one concrete particular who is God (however else God is also to be described), the goal for theology includes centrally the knowledge of persons. That is why it makes sense that Judaism is centered on stories, in the Torah and the Talmud; and that is why the heart of the Christian evangelium is in the stories of the Gospels. The propositional knowledge of philosophy will be useful to theology, but only as part of the means for the knowledge of the person who is God, and that knowledge cannot be appropriately conveyed without narratives.

\section{BIBLIOGRAPHY}

ABBREVIATED REFERENCES to WORKS BY THOMAS AQUiNAS

STh Summa theologiae

SCG Summa contra gentiles 


\section{LITERATURE}

ALter, Robert. The Art of Biblical Narrative. New York: Basic Books, 1991.

AuERBACH, Erich. Mimesis: The Representation of Reality in Western Literature. Translated by Willard Trask. Princeton, NJ: Princeton University Press, 2003.

Ludlow, Peter, Yujin Nagasawa, and Daniel Stoljar (eds.). There's Something about Mary: Essays on Phenomenal Consciousness and Frank Jackson's Knowledge Argument. Cambridge, MA: MIT Press, 2004.

Moore, Derek, Peter Hobson, and Anthony LeE. "Components of Person Perception: An Investigation with Autistic, Non-Autistic Retarded and Typically Developing Children and Adolescents." British Journal of Developmental Psychology 15, no. 4 (1997): 401-23.

Schellenberg, J. L. Divine Hiddenness and Human Reason. Ithaca, NY: Cornell University Press, 1993.

Schellenberg, J. L. The Hiddenness Argument: Philosophy's New Challenge to Belief in God. Oxford: Oxford University Press, 2015.

STUMP, Eleonore. Aquinas. New York: Routledge, 2003.

Stump, Eleonore. Wandering in Darkness. Narrative and the Problem of Suffering. Oxford: Oxford University Press, 2010.

StumP, Eleonore. "God's Simplicity." In The Oxford Handbook of Aquinas, edited by Eleonore Stump and Brian Davies, 135-46. Oxford: Oxford University Press, 2011.

Stump, Eleonore. "Athens and Jerusalem: The Relationship of Philosophy and Theology." The Journal of Analytic Theology 1, no. 1 (2013): 45-59.

STUMP, Eleonore. "Simplicity and Aquinas's Quantum Metaphysics." In Die Metaphysik des Aristoteles im Mittelalter: Rezeption und Transformation, edited by Gerhard Krieger, 191-210. Berlin: De Gruyter, 2016.

StumP, Eleonore. The God of the Bible and the God of the Philosophers. Milwaukee: Marquette University Press, 2016.

Turnbull, Colin. The Forest People. New York: Simon and Schuster, 1968.

\section{THEOLOGY AND THE KNOWLEDGE OF PERSONS}

\section{S u m m a r y}

The aim of the paper is to discern between philosophy and theology. A philosopher is looking after impersonal wisdom, a theologian searches for a personal God. This differentiation is fundamental because knowledge of persons differs from knowledge that. The author shows how taking into account the fact that theology is based on the second-person knowledge changes the way one should approach the hiddenness argument.

Keywords: divine hiddenness; knowledge of persons; second-person knowledge; narrative knowledge. 


\section{TEOLOGIA I WIEDZA O OSOBACH}

\section{Streszczenie}

Celem artykułu jest ukazanie różnicy między filozofią a teologią. Filozof szuka mądrości bezosobowej, teolog zaś szuka Boga osobowego. To zróżnicowanie jest fundamentalne, ponieważ wiedza o osobach różni się od wiedzy o przedmiotach. Autorka pokazuje, jak uwzględnienie faktu, że teologia opiera się na wiedzy drugoosobowej, zmienia podejście do argumentu z ukrytości.

Słowa kluczowe: Boże ukrycie; wiedza o osobach; wiedza drugoosobowa; wiedza narracyjna. 